\title{
. \\ Reviving Taiwan's craft bamboo industry: Evaluating recent strategies to transform a heritage craft sector into a contemporary cultural industry
}

\author{
Hung-Wei Lee / Carolyn Barnes / Gianni Renda / Swinburne University of \\ Technology / Melbourne / Australia
}

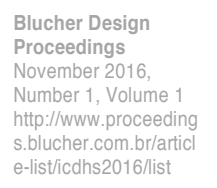

\begin{abstract}
Policy-makers increasingly see cultural industries as important economic contributors with the added scope to sustain local identity. Since 1991, Taiwan's Ministries of Culture and Education have sought to revive Taiwan's bamboo crafts, including for their cultural heritage value, in the face of damaging competition from cheap imports. Various policies and programs have sought to give new strength and vitality to Taiwanese cultural production. Despite some noteworthy individual products, such efforts typically neglect the root causes for the decline of Taiwan's bamboo industries. Research suggests that successful cultural industries need a critical mass of creative innovators, entrepreneurs and skilled workers and advanced manufacturing capability. The paper discusses industry development strategies to date, arguing that the main hurdle to the revitalization of Taiwan's bamboo industries is a lack of an innovation culture in manufacturing companies to drive new product development compounded by design graduates' limited exposure to bamboo as a material.
\end{abstract}

\section{Keywords}

Bamboo products, cultural industries, design policy and innovation, design curriculum

\section{Introduction}

Taiwan's bamboo products encompass works of craft and manufactured goods. The main bamboo crafts are weaving, carving and bolt-chisel bamboo furniture. Manufactured products include blinds, birdcages, chopsticks, lampshades and lighting, swords, tea trays and toothpicks. A separate field of production is bamboo flooring through high temperature compression and laminating techniques.

Taiwan's 1987 policy of economic liberalization contributed to a climate that has seen the de-

cline and restructuring of Taiwan's bamboo industry. Many bamboo manufacturers have relocated to China, creating less demand for Taiwanese bamboo and prompting Taiwan's farmers to replace their bamboo plantings with other crops. The centre of bamboo craft and timber production in Taiwan is Zhushan Town, Nantou County. Industry decline has contributed to the closure of the specialist bamboo craft education program at National Zhushan Senior High School in 2010, further jeopardizing the future of Taiwan's bamboo products sectors. This paper considers the potential to revive Taiwan's bamboo industries through design-led innovation, transforming them into a contemporary cultural industry.

\section{Creative industries}

Since the early 2000s, a consensus among academics and policy-makers identifies cultural industries as new drivers of economic growth (Scott, 2006, Currid and Connolly, 2008, Pratt and Jeffcutt, 2009, Reimer et al., 2008, Florida, 2002). Kong (2014), however, argues that as governments internationally rush to implement creative industries policies, caution should be exercised due to a lack of conceptual clarity around the nature and operation of creative industries, with more research being needed about what is happening on the ground. Taiwan's Department for Culture, Media and Sport's (DCMS) Creative Industries Taskforce (1998) defines creative industries as having their origin in individual creativity, skill and talent, their scope for wealth creation being linked to the generation of intellectual property. DCMS was an early adopter of the term 'creative industries', coined in 1997 by the UK government as a classifier for a new, emerging areas of industry linked to the melding of commerce and human creative capacity 
(Mommaas 2009, 51; O'Connor 2011, 38). In the UK case, recognition of growing employment and revenue through this alliance prompted efforts to promote and support its economic contribution (Banks and O'Connor 2009, 365). Pratt (2007) argues that creative industry policies show that innovation and creativity are no longer seen as the sole preserve of high-tech firms, with Brandello and Kloostermann (2010) noting the example of high-concept activities in consumer and producer services. The idea of creative industries proposes a new economic model in which social and cultural relations fuse with the 'economic'. Unlike traditional engines of economic growth such as manufacturing, creative industries produce goods and services in which subjective and symbolic meanings outweigh utilitarian purpose (Shultz, 2013). It is thus argued that creative industries do not only produce economic outcomes, but also have an affect on social and cultural relations at macro and micro levels. Yue (2006), for instance, discusses how global informational capitalism has realigned regions, nations, markets and identities over the last two decades, seeing the governance of culture in the Asia-Pacific region experience rapid and profound modernisation and development through the shift from manufacturing to cultural production.

Yue (2006) gives the example of Singapore's use of culture to create new industries and services business, with the perception that their nature promotes Asian culture and values, an effect outside the standard paradigm of production, distribution and economic exchange through consumption. For several decades now, state discourses in many Asian nations have leveraged tangible and intangible cultural heritage and the cultural output of individuals or groups to challenge to Western imperialism. Sheridan (1999, p. 3) describes their efforts to use culture 'to renew societies, to reconnect them with their past, to overcome the legacy of colonialism and the old assumption of white supremacy to find a way of life that is both modern and yet true to the traditions of Asian societies'. The ideology of Asian values has been cultivated in Asia to ease societies' transition into postmodernity and the global era, the creation of new Asian cultural capital being seen as integral to the development of the general prosperity, but also creative wealth of contemporary economies (Yue, 2006).

\section{Taiwan's creative industry initiatives}

International models for the development of creative industries have strongly influenced the Taiwan government's effort to revive heritage arts and crafts as a source of economic and social benefit on different fronts. Taiwan's 2010 'Cultural and Creative Industry Development Act' merges aspects of the UK's 1998 'Creative Industries Policy', the UK's 2001 'Creative Industries Mapping Document' and the United Nations' 2008 'Creative Economy Report'. These reports draw on significant research into creative activity and its economic value in economies at different stages of development, often stressing the benefits of combining traditional culture and new technologies to stimulate culturally meaningful economic activity. The 2008 'Cultural and Creative Industry Development Law' saw the Taiwan government seek to both promote Taiwan's cultural brand internationally and raise the level of community cultural engagement. The policy included a national plan for cultural workers, academics and government to collaborate on cultural and industry development. Later, the General Provisions of Taiwan's 2010 'Cultural and Creative Industry Development Act' set out an ambitious agenda for the development of Taiwan's cultural and creative industries through the use of 'new technology and innovative research and development' combined with sound 'training of cultural and creative industry professionals' (Taiwan Culture Ministry, 2010). Taiwan's bamboo crafts and products sector was included as a field for funding within Taiwan and internationally to address more than three decades of decline.

There had now been a series of government efforts to support traditional arts and crafts. In

1991, for example, the government instituted the 'Local Industry Promotion' program, using case studies from Japan to show how Taiwan's artists and craftspeople might actively preserve, develop and promote their work. In 1995, the Ministry of Education and Ministry of Culture founded a National Arts Award, a Heritage Award and the National Technology Achievement Award to promote the nation's traditional arts, crafts and industries. Efforts to foster active cooperation between manufacturers, crafts people and academia was also funded through the Taiwan Design Centre and the National Taiwan Craft Research and Development Institute. A 2007 program matched leading designers with bamboo product manufacturers to jointly develop more innovative, desirable products.

After several funding rounds, some products have achieved international recognition, for example, the 'Bamboo 43' chair designed by German industrial designer Konstantin Grcic and fabricated by the Taiwanese bamboo master Chen Gaoming. The chair received international acclaim at the 2009 Maison \& Objet Expo, Paris, but its design points to major hurdles to the renewal of Taiwan's bamboo products sectors. Collaborating designers had little understanding of the material characteristics of bamboo and no Taiwanese manufacturing company had the equipment or technical staff to mass produce Grcic's complex design (Lin, 2012). Significant time and effort was 
invested in adjustments to enable production, with only single showroom display models being produced. Recent work with state- of-the-art rapid prototyping technology has still not resulted in the mass production of any bamboo consumer products from the initiative (Taiwan Design Center, 2015).

\section{The skills and knowledge deficit}

Traditionally, bamboo goods in Taiwan were folk crafts, seeing skills and knowledge handed down from generation to generation. The Japanese established formal training in bamboo crafts during their colonization of Taiwan (18951945). In 1938, the Japanese established the Zhushan Town Bamboo Craft Heritage Learning School, to teach boys who had graduated from elementary school learn bamboo-weaving techniques, with the government paying for their tuition and lodging. The School pioneered the development of local craft industry based on studio craft techniques. From 1952, the Nantou County Government promoted bamboo crafts through workshops (Wong et al., 1998) and by establishing the Nantou County Crafts Research School in 1954 (Yang 2015), building a base for the growth of Taiwanese bamboo crafts industry up to the early 1980s.

Many of the bamboo craft workers trained at National Zhushan High School continue to be in-

volved in studio craft production, but this is an approach increasingly out of step with contemporary market conditions. In emphasising making skills, craft workers' training lacked exposure to design principles, affording little capacity to critically assess products against broad market expectations and developments. National Zhushan High School phased out its bamboo craft course in 2010, leaving a gap in technical education for bamboo products. Some training in bamboo crafts is available through intermittent, government-funded courses in heritage skills. Some universities offer single units in bamboo craft techniques and design, but the skills and competencies required to work with bamboo as a material are no longer available $\mathrm{n}$ in Taiwan to the level required to sustain an industry, much less modernise one.

\section{Design innovation and industry-scale renewal}

The present should be a favourable time to market craft products and bamboo goods form Taiwan. The West's ongoing interest in Asian culture continues (Zeng 2004). Murray (2010) discusses consumers' admiration for craftsmanship and enjoyment of the tactile qualities of hand-crafted items in contrast to the character of mass produced goods. Many consumers welcome products that use sustainable materials like plantation bamboo. However, a craft model of industry organization is increasingly difficult to sustain in the face the turbulent business environmental created by globalisation, which for seen cheap imported alternatives erode the local market for products like Taiwan's bamboo goods, making many traditional craft industries unviable (Murray 2010). Hareven (2003) argues for a stress on the symbolic value of authentic products rather than practical function to differentiate them from imitators, but de Waal (2002) sees a risk in developing products purely to appeal to consumer sentiment, which can quickly change.

Taiwan's bamboo craft studios and manufacturing companies are small-to-medium sized businesses, most being family-owned and traditional in outlook, being poorly placed to navigate the web of challenges and opportunities described above. Most lack marketing capability, especially the market information to withstand the impacts of globalization, which Chandasekharan (2005) argues requires sophisticated understanding of diverse factors such as product development and pricing, marketing approaches and practices, market channels and potential institutional support. Cunningham (2006) likewise describes the related challenges of contemporary product planning, which depends strongly on effective product research, promotion and distribution to meet the needs and interests of consumers to ensure adequate earnings

Most research into innovation in new product development (NPD) focuses on large firms, Chrisman and Patel (2012) arguing for more research into research and development activity in family owned SMEs. Their research identifies a consistent negative relationship between family ownership, R\&D intensity, and product and company performance. Bolton (2009) reports that family firms typically invest less in R\&D than non-family-owned firms. Family-run firms also typically lack expertise in design management, which Roberto (2008) argues helps companies to get closer to consumers, their needs and preferences. Design-driven innovation is practiced at its most advanced level by successful Italian manufacturers such as Alessi, Artemide and Kartell, international leaders in their industry despite being relatively small-sized companies (Roberto 2008).

Shah (2000) argues that successful product innovation derives from two main sources; information transfer between lead users and manufacturers and relative perceptions of the benefit of innovation between users and manufacturers. Roberto (2008) contends that design-driven innovation in companies occurs in two major 
dimensions: 1) market-pull innovation that begins with the analysis of consumer needs and preferences, leveraging the nuanced, tacit undercurrents within socio-cultural groups to search for the technical means and aesthetic and symbolic languages to fulfil them and 2) technology-push innovation that harnesses the dynamics of technological research. Both Shah (2000) and Roberto (2008) recommend design-driven innovation as the way to push a company's vision around new products. Jan (2003) favours an activity-based division of the NPD process across the stages of idea generation, idea screening, commercial evaluation, technical development, testing and commercialization, but notes that in large companies innovation is equally a distributed process that needs strong coordination across the $R \& D$, design, engineering, production and marketing departments of a company. More pertinent to small, craft-based firms is Shah's (2000) argument that companies can benefit from personal use of their products to understand their level of innovation.

Arguably, all of these strategies would aid Taiwan's bamboo products manufacturers to develop new products. We are currently analysing a body of qualitative interview research into NPD in Taiwanese bamboo manufacturing businesses to address a lack of knowledge about what is happening here, with the raw data suggesting a raft of deficits including a lack of design and design management expertise. Sciascia et.al. (2015) argue that for the long term, small family businesses - this being the pattern for Taiwan's bamboo manufacturing companiesbusiness goals are typically shifting and varied. Where family wealth and company equity closely overlap, R\&D levels are adversely affected because of owners' overriding motivation to protect family wealth and status. Tang et al. (2014) argue that as the intersection between family wealth and firm equity reduces, this fosters raised R\&D activity due to long-term aim of increasing family prosperity balances the risk of low investment in R\&D.

Sciascia et.al. (2015) make two recommendations for SME owners and managers aiming to raise $R \& D$ intensity. Firstly, where the overlap between family wealth and firm equity is low, family owners should invest more in the R\&D to raise the benefits of family ownership. Secondly, where the overlap between family wealth and firm equity is high, family owners should open to offering equity to other owners such as angel investors or private equity to reduce the risks to family wealth while raising the level of R\&D activity. The low profile and sectorwide decline of Taiwanese bamboo craft studios and product manufacturing companies makes such investment unlikely. Other authors highlight the challenges for companies that wish to secure financial profits from their innovations through intellectual property protection and licensing agreements, which has been a problem for Taiwan's bamboo manufacturing companies, who have seen their products copied by low-cost manufacturers, including in substitute materials such as plastic. Companies need to keep ahead of the innovation curve to capture profits during the time when they still have an advantage over companies that come along to mimic their innovations.

Fundamental to all models of design-driven innovation in NPD is the manufacturer's role to identify market needs, then use design and technology innovations to fulfil these (Magnus and Siri, 2015). Other writers describe product innovation within individual firms as substantially as case of locally- driven behaviour, where business owners and staff need to have both an intuition for and knowledge of what they are doing (Dorst, 1997, Valkenburg, 2000). The shift in Taiwan's economic base, combined with neoliberal policy reforms has polarized the country's manufacturing sector, with companies in high-tech industries succeeding in appreciating this and old-style manufacturing sectors such as in bamboo products falling into a malaise that blocks any such recognition. Djelic and Antti Ainamo (1999, p. 622) highlight the way that companies in the luxury fashion industry in different national contexts have worked together to whether turbulence in the international economic environment by reorganizing around different network forms, 'the "umbrella holding" company in France, the "flexible embedded network" in Italy and and the "virtual organization" in the United States.' Currently, the constraints and opportunities for Taiwan's bamboo manufacturing companies are being addressed at the level of government.

\section{Conclusion}

For the Taiwan government, both the revitalisation of heritage crafts to refocus attention on Taiwan's cultural origins and the need for economic and social development through creative industries are a concern. Policy and revitalization programs are constrained in the case of Taiwanese bamboo studio crafts and manufactured products because responsible government agencies have insufficient information to frame their approaches (Cheng and Won, 2010, Karppinen, 2008, Yao et al., 2013, Taiwan Labour Ministry, 2014). Much of the existing data is poorly analysed and offers a limited guide to policy development and industry support initiatives. With limited and outdated data, there is presently little scope to predict the ongoing feasibility of Taiwan's bamboo crafts and manufactured products sectors. Moreover, our paper suggests that bamboo studio crafts and bamboo manufactured products are distinct fields with 
individual challenges, each needing their own remedies.

The revitalisation of Taiwan's manufactured bamboo products sector requires the urgent injection of enhanced capability in design, design management, manufacturing systems and marketing on an industrywide scale to withstand the impact of sharp, multilateral global competition and increasing customer expectations. Broad industry development in a sector dominated by small to medium-sized, family-owned firms will need to overcome significant historical legacies, but it is undoubted that the industry will need to come together to achieve the required innovation in manufacturing processes and new product development. Currently, the only positive for the Taiwanese bamboo manufactured products sector is the interest of relevant government departments in jointly negotiated industry development through financial aid and guidance. Modernised industry and company practices and government support, however, need to be accompanied by efforts to address an additional barrier, the lack of designer graduates with a knowledge of and interest in bamboo as a material for product design.

\section{References}

Banks, M. \& Connor, J. (2009) 'After the Creative Industries'. International Journal of Cultural Policy, vol. 15, no. 4 , pp. 365-373.

Bolton, S. (2009) 'The Value of Design-led Innovation in Chinese SMEs'. In Proceedings of the 19th CIRP Design Conference-Competitive Design. Cranfield University, 30-31 March, pp. 369.

Brandellero, A. M. C. \& Kloosterman, R. C. (2010) 'Keeping the market at bay: Exploring the loci of innovation in the cultural industries'. Creative Industries Journal, vol. 3, no. 1 \& 2, pp. 61-77.

Cheng, H.-L. \& Won, H.-J. (2010) 'The Strategies of Local Industrial's Structure Transformation and Space Renovation [地方產業轉型再生與空間再造策略之研究_以南投縣青竹竹文化園區為例]'. Architectural Society.

Chrisman, J. J. \& Patel, P. C. (2012) 'Variations in R\&D investments of family and non-family firms: Behavioral agency and myopic loss aversion perspectives'. Academy of Management Journal, vol. 55, no. 4, pp. 976-997.

Cunningham, S. (2006) 'What Price a Creative Economy'. Platform Papers, no. 9, July, pp. 1-50.

Currid, E. \& Connolly, J. (2008) 'Patterns of knowledge: the geography of advanced services and the case of art and culture'. Annals of the Association of American Geographers, vol. 98, no. 2, pp. 414-434.

Djelic, M-L. \& Ainamo, A. (1999) 'The Coevolution of New Organizational Forms in the Fashion Industry: A Historical and Comparative Study of France, Italy, and the United States'. Organization Science, vol. 10, no. 5, pp. 622-637.

De Waal, E. (2002) Altogether elsewhere: The figuring of ethnicity, London, A \& C Black. Department For Culture Media Sport (1998) Creative industries mapping document. London, Department for Culture Media Sport.

Dorst, C. H. (1997) Describing design, a comparison of paradigms. Doctoral Thesis, Delft University of Technology.

Florida, R. (2002) 'The economic geography of talent'. Annals of the Association of American Geographers, vol. 92, no. 4, pp. 743-755.

Hareven, T. (2003) The silk weavers of Kyoto: family and work in a changing traditional industry. Oakland, University of California Press.

Huang, S.-H., Lin, X.-F., Wang, G.-Y. \& Chen, T. (1998) 'The Zhushan County bamboo craft a teaching centre of born and influence [竹山郡竹材工藝傳習所的誕生與影響]'. Japan and South Asia set Meter Symposium, pp. 897-902.

Jan, B. (2003) 'Modelling Product Innovation Processes, from Linear Logic to Circular Chaos'. Creativity \& Innovation Management, vol. 12, no. 2, pp. 76-93.

Karppinen, S. (2008) 'Craft-Art as a Basis for Human Activity'. International Journal of Art \& Design Education, vol. 27, no. 1, pp. 83-90.

Kong, L. (2014) 'From cultural industries to creative industries and back? Towards clarifying theory and rethinking policy'. Inter-Asia Cultural Studies, vol. 15, no. 4, pp. 593-607.

Magnus, G. \& Siri, A. (2015) 'Is innovation a useful concept for arts and humanities research'. Arts \& Humanities in Higher Education, vol. 14, no. 1, pp. 9-24.

Mommaas, H. (2009) 'Spaces of Culture and Economy: Mapping the Cultural-Creative Cluster Landscape'. In: LILY, K. \& JUSTIN, O. C. (eds.) In Creative Economies, Creative Cities: Asian- European Perspective. Dordrecht, Springer.

Murray, K. (2010) 'Outsourcing the hand: An analysis of craft-design collaborations across the global divide'. Craft \& Design Enquiry, vol. 2, pp. 1-24.

National Zhushan Senior High School. (2016) 'History Memorabilia [沿革大事記]' [Online]. http://www.cshs.ntct.edu.tw/.

O'Connor, J. (2011) 'The Cultural and Creative Industries: A Critical History'. Ekonomiaz, vol. 78, no. 3, pp. 24-47. 
PINE II, B. J. \& GILMORE, J. H. 1998. 'Welcome to the experience economy'. Health Forum Journal, vol. 44, no. 5, pp. 7-10.

Pratt, A. C. (2007) 'An economic geography of the cultural industries'. LSE Research online. London, London School of Economics.

Pratt, A. C. \& Jeffcutt, P. (2009) Creativity, Innovation and the Cultural Economy, London, Routledge.

Reimer, S., Pinch, S. \& Sunley, P. (2008). 'Design spaces: agglomeration and creativity in British design agencies'. Geografiska Annaler: Series B, Human Geography, vol. 90, no. 2, pp. 151- 172.

Roberto, V. (2008) 'Design, Meanings, and Radical Innovation- A Metamodel and a Research Agenda'. Journal of Product Innovation Management, vol. 25, no. 5, pp. 436-456.

Sciascia, S., Nordqvist, M., Mazzola, P. \& De Massis, A. (2015) 'Family Ownership and R\&D Intensity in Small- and Medium-Sized Firms'. Journal of Product Innovation Management, vol. 32, no. 3, pp. 349-360.

Scott, A. J. (2006) 'Creative cities: conceptual issues and policy questions'. Journal of Urban Affairs, vol. 28, no. 1, pp. 1-17.

Shah, S. (2000) 'Sources and Patterns of Innovation in a Consumer Products Field- Innovations in Sporting Equipment'. Massachusetts Institute of Technology, paper. 4105, March, pp. 1-27.

Sheridan, G. (1999), Western Dreams: Understanding the New Asia. Sydney, Allen \& Unwin.

Shultz, B. (2013) 'The Work Behind the Scenes: The New Intermediaries of the Indie Crafts Business'. Regional Studies, vol. 49, no. 3, pp. 451-460.

Taiwan Culture Ministry. (2010) 'Law for the Development of the Cultural and Creative Industries'.

Taiwan Design Center. (2015) '43 Chairs, cross-border breakthrough of technology and crafts [43 椅科技 與工藝的跨界突破]' [Online]. http://www.tdc.org.tw/news_detail82.htm.

Taiwan Labour Ministry. (2014) Plan Execution Website [Online]. 勞動部勞動力發展署技能檢定中心. Available: http://www.labor.gov.tw/home.jsp?pageno=201110210004.

Tang, C., Shang, J., Naumann, S. E. \& Von Zedtwitz, M. (2014) 'How Team Identification and Expertise Identification Affect R\&D Employees Creativity'. Creativity \& Innovation Management, vol. 23, no. 3, pp. 276-289.

Valkenburg, A. C. (2000) 'The Reflective Practice in product design teams'. Doctoral Thesis, Delft University of Technology.

Wong, X. D., Chen, T. S., Huang, S. H., Lin, M. C., Lin, S. F. \& Wang, G. Y. (1998) 'An investigation of craft resource in Zhushan and the research of countermeasure against handicraft Renaissance [竹山地區工藝資 源之調查與工藝振興對策之研究]'. Nantao: Taiwan Provincial

Handicraft Institute.

Yang, C. (2015) 'The History of Establishment of 'Nantou Handicraft Seminar' by Shui-Long Yen in the 1950s and His Achievements' [1950 年代顏水龍主持「南投縣工藝研究班」之始末及其成果之研 究]'. Design Journal, vol. 20, no. 1, pp. 25-47.

Yao, T.-H., Sun, C.-Y. \& Lin, P.-C. (2013) 'Modern Design in Taiwan: The Japanese Period, 1895- 1945'. Design Issues, vol. 29, no. 3, pp. 38-51.

Yue, A. (2006) 'Cultural governance and creative industries in Singapore'. International Journal of Cultural Policy, vol. 12, no. 1, pp. 17-33.

Zeng, S.-L. (2004) 'The Oriental heritage collections in Europe: Intellectual forces [東方文物在歐洲: 之性的 收藏勢力]', Taipei, Family of art collection.

\section{Biographical note}

Hung-Wei Lee is a PhD candidate at Swinburne University of Technology in Australia. His family has been part of Taiwan's bamboo forestry industry for four generations. Hung-Wei has implemented bamboo industry projects in Dominican Republic for Taiwan's International Corporation and Development Fund. His research investigates design-led innovation and industry renewal.

Associate Professor Carolyn Barnes (PhD Melb 2004) is Academic Director of Research Training in the Swinburne School of Design where she teaches research methods for academic and practice applications. Her research investigates how to harness the knowledge and power of individuals and groups to address their primary needs and interests.

Dr Gianni Renda (PhD Swin 2013) is Course Coordinator of the Bachelor of Industrial Design program at Swinburne University of Technology. Gianni is also Deputy Director of the Swinburne BioReactor, an ARC Training Centre developing new, empowering products and technologies for the health sector, including for disability and ageing. 